\title{
The Need-Goal Integration Hypothesis: How to Meet Identified Needs
}

\author{
Jayeoba Foluso Ilesanmi ${ }^{1}$
}

\begin{abstract}
The paper highlights the many needs/goals of stake holders in the organisation and closely examines the well-worn believe that the main role of managers is to motivate their subordinates. Argument was proposed as to why this view is not appropriate in today's organisations. The driving force for most employees, whose mobility and employability has been enhanced by ICT and globalization, is the extent to which the employing organisations is able to articulate their needs and meet them. To motivate and retain the modern day workers with portable skills, and to whom career is more a lattice than a ladder, is to be able to factor their needs into the goals of the organisation. More so, organisation is not about management and employees alone. There are many other stake holders; less visible though, but very important in the need-goal constellations of the organisation. It is posited that all stake holders in the organisation need to be motivated (by identifying and meeting their needs) though in diverse ways, and that the action and inaction of one stake holder provides impetus for adequacy or shortfall in the motivation equation.
\end{abstract}

Keywords: Need constellations, need-goal hypothesis, need-goal integration.

Available Online: $28-06-2016$

This is an open access article under Creative Commons Attribution 4.0 License, 2016.

\subsection{INTRODUCTION}

In most discussions of motivation, the traditional view is to see motivation as a one-way traffic flowing from management to the employees. This is why most definition of motivation assumes, as a matter of course, that motivation is what managers do to get their subordinates to achieve the set goals of the organisation. A critical question is, if the manager motivates the subordinate, who and what motivates the manger? The Management by Objective (MBO) approach gave us a neglected hint that motivation may be more than what managers do. In the MBO approach, work attainment is benchmarked on the inclusive role of workers in setting work targets, appraisal mode and direct participation in the appraisal (Drucker, 1954). With MBO, and for the first time, worker involvement is enlisted and became an ultimate consideration in setting organisational goals and objectives as well as rewards. This is actually only a

\footnotetext{
${ }^{1}$ Department of Industrial Relations and Personnel Management, Faculty of Management Sciences, Lagos State University, Ojo. E-mail: jayeobafoluso@gmail.com, Phone: +2348023687713,
} 
starting point. Jayeoba (2013) views organisation as a social engagement in which people come to implement a form of social, psychological and economic contract.

The implication and the important question is what are those things that make the organisation attractive to its constituent members? That is, why do entrepreneurs want to invest and the managers want to manage other people's business and went through many years of learning to be able to so do? What makes workers attain certain qualifying knowledge and skills, leaves their home environment, goes to great length and travels great distance to look for work and become engaged for more than a third of his/her lifetime? These questions are answered in the need-goal integration hypothesis (Jayeoba and Lawal, 2009; Jayeoba 2013).

The main thesis of this paper is to show, using the need-goal hypothesis, that motivation is not only resident in management actions but by and in the extent to which the needs and ultimately the goals of members of an organisation are identified, factored in and met within the context of others needs and goals.

\subsection{THE ARGUMENT}

From figure one, it is seen that the initial effort at motivation ought to start with identification of bonafide members or stakeholders in the organisation or industry. Their needs and goals once identified, efforts are directed at meeting the needs by setting goals that are contingent to the needs. According to the goal-path theory, the employee being rational examines the best path available to the attainment of his/her goals and act accordingly (Georgopolous, Mahoney and Jones, 1957). Equally, Vroom (1964) in his expectancy theory posits the valence of a goal as the main impetus for achieving motivation of workers. The organisation as a need fulfilling agent often finds it intriguing to motivate because of little attention to individual and collective needs. Motivation and reward objectives often are set to meet what in the aggregate can be said to be mainstream goals and needs. Many are left adrift and dissatisfied in such a matrix of partly fulfilled and unfulfilled needs. Performance traditionally suffers of workers as well as managers whose best efforts at achieving satisfaction and higher level of performance are hitting the brick walls.

Figure 1: Motivation as need identification and fulfillment.

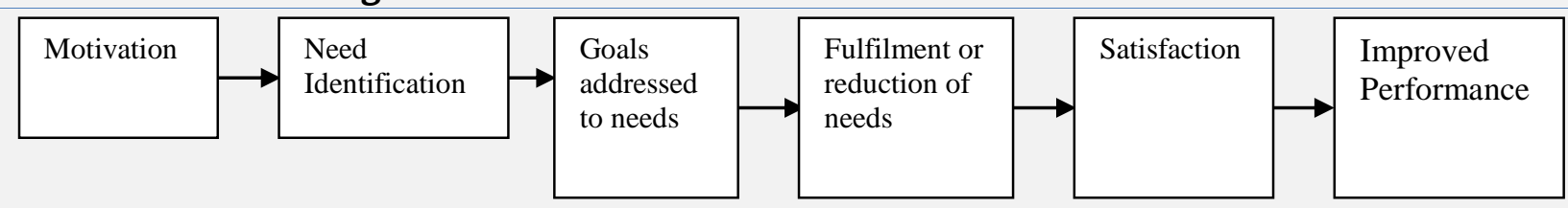

Jayeoba and Lawal, (2009)

\subsection{IDENTIFYING THE NEEDS AND GOALS OF MEMBERS OF THE ORGANISATION}

Any individual or group of people, whether internal or external, with a stake in organisation's operation or success, are classified as stakeholders or strategic constituency or strategic partners. Identifying the strategic stakeholders poses challenge of boundary demarcation. A systematic identification of individuals and groups likely to be affected by the organisations operation, products, services, success or failures is required. For instance, Roberts \& King (1989) in a sample stakeholders audit identifying strategy of a major auto manufacturer isolated seventeen constituencies including financial community, the press, local and foreign competitors, environmentalists, stockholders and different levels of government (federal, state and local) etc. The need-goal hypothesis identified nine constellations of needs such as the needs of owners, management (and perhaps management in their collectives), that is, their trade group e.g. the Nigerian Employers Consultative Association (NECA) or Manufacturing Association of Nigeria(MAN), individual employees, employees in their collective, e.g. labour unions, societal needs, needs of customers, government and indeed retirees. These needs are shown in figure two. 
Figure 2: Nonagon of needs and goals.

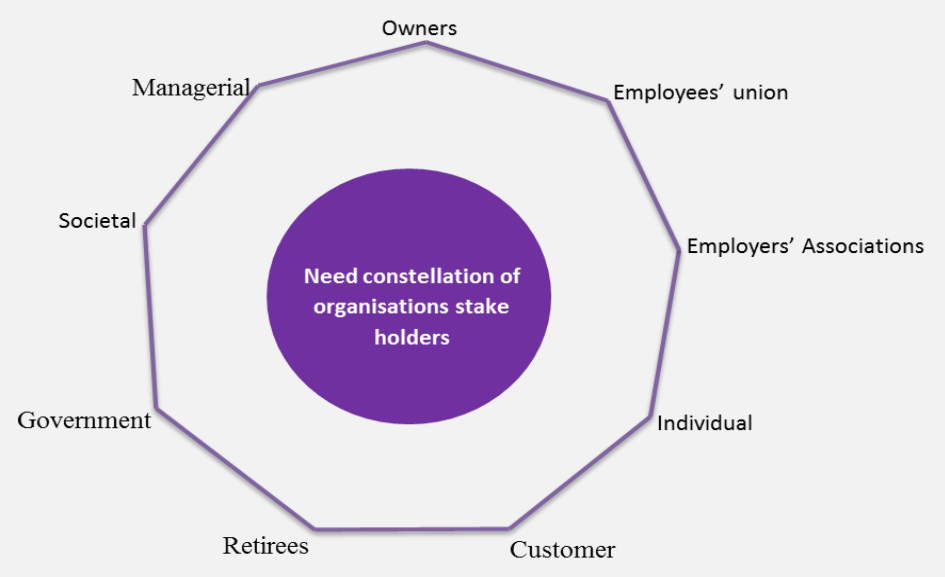

Adapted from Jayeoba and Lawal, (2009)

\subsection{THE NEXUS BETWEEN NEEDS, GOALS, SATISFACTION AND PERFORMANCE OUTCOMES.}

One of the most used frameworks for understanding individual's work-related attitudes and behaviours is the social exchange theory (Blan, 1964; Sturman \& Short, 2000) which suggests that rational selfinterest drives people's social interactions. The theory when extended to the organization sees, according to Eisenberger (1986), individuals as forming an "anthropomorphic ascription of dispositional traits to the organization" and that people tend to "personify the organization and thus see themselves as involved in exchange relationship with the organization of which they are a member". According to Jayeoba, Sholesi and Lawal (2013) commitment as well as continued membership of the organization is based on cognitive (i.e. rational) evaluation of costs and benefits of remaining in the relationship. People's commitment is calculative and individual's commitment to organization and consequent behaviour is a function of accumulated investment (in the form of payment for expended efforts, job tenure, pension, seniority and global satisfaction of needs through mean's made available by the organization).

In a collectivist society such as Nigeria, workers value interaction and are quick to respond to three important dimensions of interaction, such as distributive, procedural and interactional justice. According to Lawal (2010), organisational justice has both conceptual and practical implications. Workers in collectivist culture, as opposed to western individualistic orientation, are relationship dependent. This fact of distributive injustice is born out in the saying 'baboon dey work, monkey dey shop' which literally expresses feelings of inequitable distribution of returns. This simply put, is an illustration of not just distributive inequity, but also of procedural and perhaps also interactional injustice among organisational stakeholders. At a deeper level of analysis, motivation is about what people see, feel, think, believe and ultimately behave like. On the other hand, performance outcomes are related to the belief, feeling and thinking people hold about their work, work condition, superior/ subordinates and consequently their attitude and behaviour. Factoring of individual, group, organisational and societal needs should become the focus of motivational paradigm and conceptions to be able to input equilibrium in the weighing of objectives, goals, productivity demands and rewards to stake holders.

According to Passer and Smith (2001) whether in the context of striving for success, seeking thrills, finding a mate, or simply obtaining food to eat, motivation is a process that moves people toward their goals. Goals on the other hands, which are mental representations of what the future could be, are central issues of satisfaction. Goals according to Carsrud and Brannback (2011) activate people. They are directive; energizing and can lead to arousal, discovery and emergence of strategies to achieve identified goals. The strength of activation is however determined by the strength of motivation. Weak motivation does not often translate to action especially when the task is difficult or not feasible and reward is deficient in activating desire to surmount the difficulties. The valence of reward is related to goals set by 
the individual worker or group of worker. If the goal is important and reward adequate, there is arousal as well as energizer of positive behaviour towards achievement of the goal. Pay, as reward, is the obvious link in industries and organisations between performance and satisfaction or vice versa.

For instance, many had wondered why State universities in Nigeria often participate in strikes called on issues bothering Federal universities. Apart from belonging to the same industrial union and the solidarity of one for another, experiences have shown that action at the level of ASUU national often incorporate the needs of State universities and the benefit is tangible at the end of most industrial actions. For this purpose, the solidarity is maintained and the motivation to jointly pursue an action is strong.

Earlier works on equity of pay (Adam, 1965) and pay satisfaction (Lawler, 1971, 1981; Dyer and Theriaut, 1976; Heneman and Schwab, 1979) have tackled some of the questions relating to the causal variables of pay satisfaction as well as motivation to work. Their works in various ways have shown how workers are not concerned primarily with absolute size of pay, but with perceptual processes underlining equity of input ratios and outcomes of self and others and differentiation by individual workers between pay "should receive" and "pay receive". As they observed, where workers' perception of pay should and pay receive are similar, the individual experiences satisfaction with pay. Where pay should is greater than or less than pay receive, it is hypothesized that the individual worker feels dissatisfied with pay. Indeed, pay should receive of Lawler's conception could be widened to include, in addition to pay, other benefits that employees deem they should receive; such as good working and technological enabled environment, conducive work climate, social engagement, inclusiveness in decision making and more importantly seeing that other social partners are equitably rewarded from the proceeds of the organisation.

This latest concern is much neglected especially in developing countries such as Nigeria where the level of empathy for others is rather low. Recently, there has been much concern about social partners like the owner, society (especially the host community) in addition to the popularly marginalized employees and indeed customers. Investors as a result of economic meltdown woke up to dwindling dividends and profits on investments while the society, rather than receive stipends in the form of community social responsibility (CSR) are making strident calls for greater compensation for exploitation of naturally occurring resources which range from mineral wealth to human resource. Organisations should, as way of looking at the future, emplace policies that incorporate all available needs of relevant stake holders in their need fulfilling paradigm.

\subsection{MEETING NEEDS OF ORGANIZATIONS' STAKEHOLDERS}

It is true that there exist multiple criteria for evaluating organisational effectiveness. According to Kreitner and Kinicki (2001) well-managed organisations must necessarily mix and match effectiveness criteria to fit the unique requirements of the situation. Cameron (1980) had prescribed four strategies or approaches for evaluating effectiveness including resource acquisition, goal accomplishment, internal processes (referring to the smooth functioning with little internal strain) and strategic constituencies' satisfaction. The last according to Cameron refers to how the needs and expectations of key interest groups are at least minimally satisfied. The goal of Need-Goal hypothesis is premised on the need to maximally satisfy the needs and expectation of key stakeholders. This is the principal reason for existence of the organisation. The short and long term goals of the organisation is (ought to be) a reflection of the needs of its constituencies/stakeholders. In the real sense of the word, motivation is not what it seems. It is not what mangers do. Indeed, it is what members of the organisation do to themselves. Two definitions of motivation are useful in this proposition. Jones (1959) defined motivation as that which initiates behaviour, energizes (boosts) behaviour, sustains and terminates behaviour. The other definition is that motivation is the process involved in integration of needs, energies (mental and physical), emotions, attitudes and behaviour of a people, bearing in mind environmental variables, to achieve well-defined goals (Jayeoba and Lawal, 2009).

Managers had wrongly assumed that the initiation of work behaviour is their major activity as managers. The simple, well known fact that motivation has both internal and external impetus - intrinsic and 
extrinsic components (Herzberg, 1966) is often lost on most managers as well as organisations. Initiation of behaviour is basically a homeostatic response to environmental stimuli, which may be internal or external to the individual. The outlook that workers are the entity to be motivated is quaint and not substantiated by fact and reasoning. In the final analysis every member of the organisation needs to be motivated and what motivates each component depends largely on the extent to which their goals and incorporated and their needs met. Scenarios are created to explain this interesting phenomenon using the so identified nine stakeholders, some of which are usually ignored entities in the motivation equation. This nonagon of need constellations have widespread implication with regard to how these needs are identified, factored into the production/service process and the programme of reward that is available at the end of the day.

1. Meeting the needs of Owners. The entrepreneur invests and takes the risk of harnessing men, money and material with an eye on profit and perhaps meeting other needs such as need for independence, selfactualization and sometimes, as is now common in Nigeria, to escape from idleness imposed by unemployment and unplanned/premature sack and retirement. Whatever the business motive may have been, the bottom-line is profitability and survival into the future. The extents to which the needs of owner(s) are met depend on the ownership structure. In Nigeria, the common modes of ownership are: i. The Sole Proprietorship. This type of ownership is common and operates mainly in the informal sector. The features of these businesses are small capital, limited scope of operation, small number of employees and arbitrariness in wages and rule of engagement. They pay, in many instances below the minimum wage, evade tax and determine the needs that could be met. Proceeds from businesses are often diverted to private ends and there is little or no demarcation between private and business funds. This is because there are neither employee unions nor associations with other employers. The best practice cannot be found in terms of motivation of workers and ability to fulfill needs. Often the customer may be able to derive some level of satisfaction of their needs as they can take their businesses elsewhere. The relationship between employer and employee terminates when the latter leaves or business closes down. There is no severance package in most instances nor is there collective bargaining, agreement or any form formal employer-employee relationship as we find in formal organisations. Because needs of workers are hardly met and grievance procedure are non-operative, absenteeism and turnover is high and workers can only be coerced to work hard.

ii. Partnerships. Partnerships are structured to meet the need of the partners and perhaps also customers. In several instances, where both are active, they may be so engrossed in who takes what that the needs of employees are mostly neglected. Equally, where one partner is inactive, the other partner may either project his interest beyond normal limit or observe the rule of association. Many cases of partnership may, like sole proprietorship, leave the needs of employees unattended. Both sole proprietors and partnership has little scope for embarking on community services by way of social responsibility services.

iii. Limited Liability Businesses (LLBs) are better organised and may consciously or otherwise, cater to many needs, including owners, employees, management, customers and society. This however need deliberation, conscious and strategic planning. In many instances, limited liability enterprises pay salaries, meet the need of customers as much as they could possibly do. Many of the companies are owned by Indians, Lebanese and Nigerians. They employ mostly casual workers, pay poor wages, evade taxes and are hardly socially responsible to their location.

iv. Public Liability Organisations (PLOs) have the most effective means for meeting identified constellation of needs. Often they are bound by rules of industrial governance and best practices. Many of these have practices and procedures for meeting owners' needs which are accounted for in Annual General Meetings (AGMs). Customers' needs are assured in quality of products, prices and general marketing efforts using the mix available to them and feedback to customers' complaint. Societal needs are emplaced in the social responsibility programmes. Indeed public liability companies having access to fund and when acting responsibly can and ought to fulfill the dictum "to whom much is given, much is 
expected". They are by rule well liaised with government and its agencies and are able to meet many more needs as they are sensitive enough to identify.

2. Meeting the needs of Management. Suffice to say that management has traditionally formulated strategies for taking care of its needs through such packages as executive compensation which are unique and incorporate the needs and conveniences of its members. Hardly is there any issue in management about disgruntled/dissatisfied management teams. It appears that management has a way of compensating itself 'adequately' though adequacy is only in relative terms.

However, there are several cases of leadership failures and non-performances which are the major causes of business failures, liquidations, mergers, acquisitions and unfortunately job losses that are common fallouts. One inefficient principal of a secondary school, sensing distress, boasted in a staff meeting; "I know these are not good times for the school, but I assure you, I will be the last man standing". But he was the first to be axed by the proprietress. The school resumed prospering after his exit. Managers when they are efficient may do so using several styles. Autocracy is at the favour of task performance at the expense of human needs, while democratic management may meet needs while the task at hand may suffer at performance. This is because the manager is at random to discover what style works and what needs to meet or neglect. The need-goal hypothesis reverses the randomness in the assignment of valence to tasks, human needs and goals.

3. Meeting the needs of individual workers. Employment situation is an exchange relationship in which the employee looks forward to meeting diverse needs which are economic, social and emotional in nature. Need for career growth and development is also important in a world in which career is both ladder and lattice for attaining future aspirations. Work is therefore more than meets the eyes. Year on end, neglect of workers' needs have precipitated concerted efforts on the part of workers' collective, of which the whole field of Industrial Relations is a response. Scholars and managers understanding of the needs of workers have been broadened since the Hawthorne studies. Responses to meeting these needs however still depict Taylor's scientific management experimentation. Meeting workers' needs will typically have to focus beyond the worker as mere economic/rational entity. He/she is indeed a ramification of economic, social, psychological, historical, spiritual and physiological essences. In dealing with individual workers, one sees that every worker has different reasons for working and the reasons are as individual as the worker. But all workers work to obtain what they need from work. The question is what do they need? Will it be money? According to Kanter (2013) though money is an important incentive, it can even be an irritant if it is not fair or adequate. He also observed that money as compensation often runs out of steam quickly as a source of sustained performance. Motivated workers are deemed to be missiondriven and have feeling of positive impact on social needs. He alluded to the needs of worker as combining a need for mastery (developing deep/new skills, knowledge and capabilities), membership (opportunities to meet people across the organisation and inclusion of outside interests) and meaningful jobs (jobs that matter by contributing to the larger whole through impact on decisions; often referred to as employee involvement/empowerment).

Other needs that are important to workers are need for self-fulfillment, leadership or growth, love of what they do, accomplishment of goals, being treated with dignity and respect and so forth. It is suffice perhaps to say that individuals work for money and other personal needs (sometimes altruistic) that are dissimilar from one worker to the other. A simple illustration is the Nigerian worker who leaves home for work at 4:30 am and commutes two to three hours to get to work. After discharging eight hours of work at the office, the return journey is even more arduous and he/she may not get home till $11 \mathrm{pm}$ or $12 \mathrm{mid}$ night and does so on a daily basis, having less than four hours of sleep/rest. Amidst bumpy rides (pot holes, rushing, boarding and alighting several buses and bikes), traffic jams and fatigue (mental, emotional and physical) many factors can be fingered as contributing to motivation and performance on a typical day. His/her needs aside those highlighted, does go beyond remuneration to include better mode of commuting to work (empowerment to own personal vehicle or provision of staff bus) or even a determination of alternative mode of discharging his/her duties including flexi-hour and the need to 
work from home. In meeting the needs of workers both individual and collective needs are salient and ought to be so treated.

4. Meeting the needs of Workers Union. Needs forms the basis of association. In workplaces, workers have associated since the early $19^{\text {th }}$ century to minimize exploitation while business owners have responded through their own version of individual collectivist efforts aiming at addressing the bourgeoning influence of workers' unions and associations. In Nigeria, there are two broad umbrellas of agitation for fair wages and better working condition for workers; the Nigerian Labour Congress (NLC) which came into existence in 1976 and recently Trade Union Congress (TUC) which was a product of deregulation of trade union brought by reforms of 2004. The TUC caters to the needs of senior workers, while NLC looks over the affairs of junior workers.

The major preoccupation of unions is welfare of their members. This however does not imply solely economic concerns. Unions in Nigeria as well as Britain have evolved their activities beyond economic spheres into social and political concerns. Both countries now have labour parties, contesting and winning elections. In Nigeria, labour has instituted itself as forerunner of economic, social and political campaigns aimed at change in business and governmental policies. The needs that organisations meet by employing workers who later becomes members of a union is diverse; ranging from salaries, allowances, training, and even payment for unworked hours such as, leave of absence and strike periods. Some critics have complained and asked questions as to why workers on strike should be paid. Indeed reference is made to an enabling law stipulating a no-work-no-pay regime. This law has only been called upon to break strikes but never implemented to the letter. It may be argued that the law is perhaps not implementable and only a strike deterrent law. In reality, workers are engaged for the purposes of competence, availability and performance. Workers may argue that strike period is a protest against hostile conditions of work. As much as the protest is to correct conditions that make working difficult, the worker is indeed working and will demand to be paid.

5. Meeting the needs of Employers Association. That the business owner has a wide area of discretion in decision making is becoming almost an unrealistic assumption. The influence of trade unions has grown in two respects. One is the legislative backing by governments and parliaments; and support by international agencies such as the International Labour Organisation (ILO). Additionally, union operates on the principle of concentration of power whereas businesses operate by dilution of power. What this mean is that whereas businesses focus on such issues as competition and market share, unions operate in such a way as to show sympathy and solidarity with colleagues within and across industries. Such concentration of power is a major issue which business owners seek to tackle by forming their own association to counter the unanimity of workers and sometimes seeming bias of government in favour of the weaker party in the collective bargaining process. For a moment, competition is subordinated to cooperation. Such body as Nigerian Employers Consultative Association (NECA) is an attempt in that direction. The body exists to identify, articulate, harness, present and argue the case for their members often in defense of erosion of their influence and control over the means of production and reward systems within the economy.

6. Meeting the needs of the society. Meeting the needs of the society can be viewed from the extent of obligations met to government and the location of the business. Location serviced depends on the scope of operations and size of business. Some businesses have local, national or international scope and the expectation that they will articulate and meet needs also cuts across these dimensions. Instances from the Niger Delta of Nigeria can easily suffice. Of course international examples of societies ravaged by civil and political uprisings are fitful, especially where such strives are brought about by economic competition and attempts of the society to resist exploitation. The case of South Africa is typical where economic concerns of Europeans led to political control of Africans for centuries leading to agitations and concerted struggle for both economic and political freedom. In the view of Idowu (2011) "the Niger Delta communities was criminally neglected by the Federal Government and the oil exploring companies. The community responded initially by mounting road blocks and shutting the gates of oil companies. 
When these did not produce the desired results, pipelines vandalisation, blowing up of oil installations, bunkering and hostage taking were resorted to. As a result of the crises, volume of explored oil reduced, oil workers operate in an insecure and hostile environment, and frequently, the Nigeria Joint Military Force (JMF) and the Niger Delta youths had clashed leaving casualities on both sides", untill the Amnesty programme of government brought temporary reprive. In particular, the oil companies took the needs of their immediate environment for granted for a long while. Such needs as employment of indigenous labour, meeting social and infrastructural needs through corporate social responsibility. More so, the farming lands were exploited for petroleum and consequently subject to degradation. The fall out was years of repressed civil and social action which culminated in militancy and expulsion of oil corporations from several communities where mining activities were hitherto occurring. During such interregnum, concerned organisations not only lose profitable businesses but also social/economic relevance.

Owners are not motivated to invest, managers have nothing but crises to manage and workers are demotivated and do often lose their employment. This example shows that for healthy corporate existence and survival, a positive social image is imperative and this can be achieved by initiating and encouraging positive reactions from members of the community in which the business is located through socially responsible acts. As reciprocity, the society makes demands on products and services, supply human resource and if economically empowered, may buy into the company's equity to keep the entity in business.

7. Meeting the needs of customers. The business world often mouths the cliché that 'the customer is king' but in reality, the business owner is and in many cases even see their products as unassailable, necessary and cannot-do-without. In Nigeria, example can be drawn from both former monopolistic PHCN (as this paper is being prepared, the Federal Government of Nigeria completed the privatization of PHCN by handing them over to private investors) and companies operating in the communication sector. PHCN has for many years offered less than desirable services which is forcefully paid for by consumers via speculative billing (actual meter reading not taken). In normal practice, customers pay for meter, buy and install poles and transformers which are items that should be supplied free by distribution companies (DISCOs). Customer's complaints are treated with threats and disdain and when they angrily disconnect from service, they are to discover to their chagrin that bills keeps coming. Service providers in the communication sector offered a mix of essential services which range from telephones, short and voice messages to data based and online services. After a decade of operation, drop calls, poor networks, unsolicited messages and ads, expensive airtime and several other disadvantages are being passed to consumers with little or no concerns.

The phenomenon of organisational stealing which means 'earning income without commensurate service or no service at all' pervades many aspect of Nigerian life; government, businesses, education and so forth. Where the consumers have real alternatives, the implications of poor service delivery are obvious. Otherwise, the consumer goes unsatisfied and may respond via apathy, passive resistance or by legal redress; albeit this is not often common in Nigeria (Jayeoba, 2008)

8. Meeting the needs of government. Perhaps in this respect it is more expedient to view the larger picture of government, not just in terms of demands from Federal, State and local government but also involving governmental agencies, parastatals and all the legal apparatuses of the state that bears directly on the operation of businesses. Most organisations in Nigeria are familiar with widespread duplications in terms of due obligations to several layers of authorities. For instance, a typical limited liability company operating in Lagos has obligation to pay the following dues (aside from those involving business incorporation and registration) to the State Government; land use charge, tenement rate, PHCN bills (whether electricity is available or not), LASAA charges for advertisement and many others.

These are also required by law to set aside 7.5 percent of employees' salaries as contribution to pension and are equally required to contribute varied percentages of profit to Education Tax Fund (ETF), ITF and NSITF. The problem of multiple taxes is particularly noticeable in Nigeria. Amaefule (2013) observed in his column in The Punch Newspaper the prevalence of multiple tax regimes in many states in the country. 
Quoting the Minister of Finance in the President Goodluck Jonathan led administration, "multiple taxation was harmful to the economy as it increases the cost of doing business, discourages local trade and investment and gives negative perception of the business environment". According to the Manufacturers Association of Nigeria (MAN), some states have as many as 97 different taxes, levies and charges that are imposed on businesses. This is in spite of the introduction of Taxes and Levies (Approved list of Collection) Act of 1998. Many business owners have no clear understanding of these requirements and as such do not factor them into their costs and are subsequently bogged down once the demands start pouring in. For public liability companies, the demands are much more, cutting across all tiers of government; Federal, State and Local governments.

9. Meeting the needs of retirees. To many scholars, retirees are never important consideration in labour relations. In Nigeria however, their cases continued to be a sad reminder of how organisations are not meeting needs of its constituents. According to Fajana (2000), industrial relations only cover relationships existing among actors up to the point of exit of workers. The view however need qualification as issues of pension (payment, non-payment or delays and even adjustment to meet economic realities) may generate issues with incumbent, retiring or retired workers. In Nigeria today, especially in the public sector, pensioners are organised into union and do sometimes influence the course of industrial life by mounting social pressures or by embarking in nominal industrial actions/protests thereby disrupting normal business activities. It is also expedient to note that whether the worker is surgically excised from the organisation at the point of retirement or not, their livelihood continued to depend on either the 'generosity' or thoughtfulness of disengaging organisation.

The new pension reform Act of 2004 suggests such a clean break through the contributory pension but left almost unresolved the issue of gratuity, which is a quantum fund for retirees to start off a new life or become economically independent. Whether said or done, the economic indices of a retiree is tied to the policies of the organisation, one way or the other. Many retirees also do come back as business partners, distributors, adjunct staff, consultants and indeed customers depending on their skills and economic leverage. They are, like the larger society, important social and economic stake holders. They could turn out as good or bad ambassadors of the organisation they once worked for.

\subsection{BASIC HUMAN NEEDS}

It is useful at this point, to understand how needs evolved in individuals. Three sources of needs can be identified:

1. Primary needs. The hypothalamus structure of the brain has been identified (Passer and Smith, 2001) as the source of basic biological needs (for food, water and sex), which predate work and do in fact lead to membership of organization. These are needs existing in individuals as well as society at large, which industries are built to meet. All industrial products and services are addressed to meeting needs; physiological, social and cognitive (Jayeoba and Lawal, 2009). An individual feeling the need for food, shelter, and other means of survival joins the organization because he believes these needs will be met therein.

2. Secondary needs. They are derived from work, especially from the goal and objectives set by the organization to which they subscribe. Need for specialized skills, upgrade of educational status, improved condition of work, understanding and use of new technology, integration into team and such other needs that are work derived.

3. Tertiary needs. This level of need derives from perceptual adjustment of individual worker to primary and secondary needs. The adjustment, which is a function of past experiences (e.g. deprivation or satiation), has social and psychological implications on work, productivity and industrial relations. The needs above can be totally, partly, or not at all met (Adams, 1965). The individual in an attempt to adjust to any of the situations arising assumes needs that assist in coping with felt dissatisfaction. Such may assume the need for worker to organize into a trade union, look for another work and any other attitude and disposition that diminishes however temporarily felt dissatisfaction. 
Also, Jayeoba and Lawal, (2009) had espoused three basic needs. This configuration of needs actually is not a disregard of Maslow's need hierarchy but a refinement. These needs are categorised as physiological, social and cognitive. Whether they are structured in the hierarchical levels (physiological, safety, love, esteem and self - actualization, Maslow, 1943) or two levels: higher (motivators) and lower (hygiene), Herzberg, 1966) or three levels (existence, relatedness and growth, Alderfer, 1969), needs basically are of three types:

1. Physiological: Which are addressed to renewal of the human physiological systems i.e. maintenance of homeostatic balance within and outside the human organism. Such needs as food and air serves for respiration (cellular and external) which maintains energy level, sugar - blood - oxygen and ion balance. Clothing is for warmth, sex for reproduction and security is freedom from danger, death, incapacitation, and possibly extinction. More explicitly stated by Cannon (1932), physiological needs refers to homeostatic (i.e. automatic) efforts of the body to maintain constant, normal state of the blood stream through the processes that maintains water, salt, sugar, protein, fat, calcium, oxygen content of the blood. Also included is the maintenance of constant hydrogen-ion level (i.e. acid-base balance), constant temperature and adequacy of other minerals, vitamins and hormones.

2. Emotional needs: Emotional needs are derived from feelings and subjective evaluations. These needs range from the need to interact with / withdraw from others of similar or dissimilar backgrounds in terms of gender, race, socio-economic status, age and such like other factors of individual differences of which intelligence, educational level, etc. are some. Affiliation needs exist at several levels depending on the degree of individual's involvement in organisational activities. Involvement can range from slight, e.g. workers in different departments of the same organization who have casual contacts in canteens or similar fora to deep, i.e., strong attachment like the case between a mentor and protégé. Emotional involvement can also be passionate like heterosexual love relationship between male and female or otherwise (e.g. gay relationship in some instances). The extent to which the work place can satisfy deep passionate relationship of male/female category has not been ascertained in literature. Experience shows that such needs though discouraged (officially) do thrive in many organizations and have implication for the work place in terms of motive for work, productivity, rule observance and maintenance of discipline. Other emotional needs are the need for recognition, dependence or autonomy, security of tenure, freedom from fear and such like. Essentially these needs are based largely on subjective feelings of the workers.

3. Cognitive needs: The need involves the use of cognitive capacities of perceptual, intellectual and learning. According to Maslow, (1943) these cognitive capacities are adjustive or adaptive tools involving a search for knowledge, truth, and wisdom; curiosity, exploration, desire for facts and the ever-persistent urge to solve existential and cosmic mysteries. These are met through different forms of intellectual stimulation based on rational evaluation of deficiency or otherwise of felt needs. These are the need for growth, creativity and problem solving, the need to achieve purpose in life, the need to dominate/adapt the environment, the need for freedom from ignorance, hunger, fear, ill-health and so forth. The more intelligent (moderated by education and perhaps hierarchy in the organization) the more cognitive needs that are felt.

To a large extent, there is no fine line between emotional and cognitive needs other than the fact that one is subjective and the other objective in nature. Also one need type can at one point or the other assume the character of the other need. For instance, a plate of rice, which meets physiological need for food, can become emotional where there is preference for type of rice, manner of cooking or what accompanies the serving of the plate of rice. Ones level of intelligence or social status can interact with the above or mode of eating rice or general satisfaction of any of physical, emotional or cognitive needs. That needs assume differences in characteristics and manner of presentation, depending on individual(s), organization and society involved is perhaps one point that has been less emphasized by motivational theories. A broad yardstick for meeting needs has been the rule. It is however important to know these important facts about needs. 
1. One need type can assume the character of another.

2. A need that is satisfied though stops to motivate or control behaviour, can reappear in similar or other form either at greater, equal or lesser intensity.

3. Needs exists on a continuum from least to highest level of deficiency/intensity, for instance figure three depicts need types as they exist on a continuum of absolute lack of satisfaction to total satisfaction

\section{Figure 3: Types of needs}

i. Physiological needs

\begin{tabular}{|c|c|c|c|}
\hline $\begin{array}{l}\text { Air, } \\
\text { Water, }\end{array}$ & absolute lack & Total satisfaction & $\begin{array}{l}\text { Air, } \\
\text { Water }\end{array}$ \\
\hline $\begin{array}{l}\text { Food, } \\
\text { Cloth/shelter } \\
\text { Sex }\end{array}$ & mil & tisfaction & $\begin{array}{l}\text { Food, } \\
\text { Cloth/shelter } \\
\text { Sex }\end{array}$ \\
\hline
\end{tabular}

ii. Emotional needs

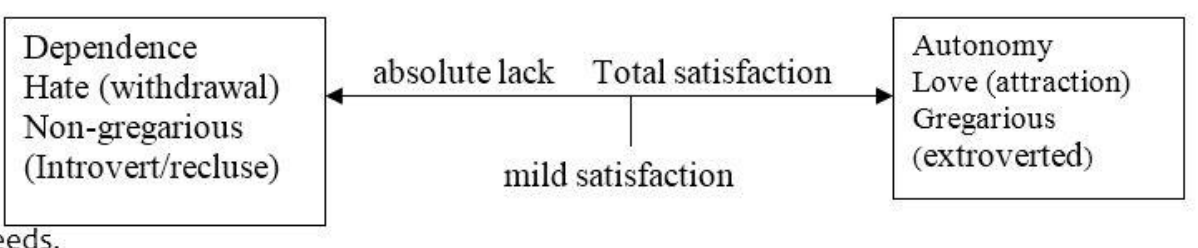

iii. Cognitive needs.

Autonomy

Love (attraction)

extroverted

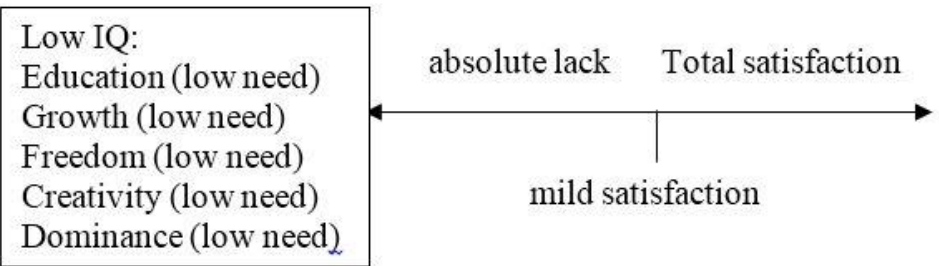

High IQ:

Education (low need)

Growth (high need)

Freedom (high need)

Creativity (high need)

Dominance (high need)

\subsection{ANOTHER CLASSIFICATION OF NEEDS}

Also need is both concrete and abstract in nature and is fulfilled respectively by extrinsic and intrinsic rewards. The demarcation between concrete and abstract needs is often said to be as blurring as the demarcation between extrinsic and intrinsic rewards. Maslow had observed that the person who thinks he is hungry might actually be seeking more for comfort or dependence than for vitamins or proteins. It is the opinion of this writer that differences exist between concrete and abstract needs. Concrete needs can however transmute to become abstract needs. Most physiological needs (also described as hygiene and existence needs) are concrete in nature, something needed for existential purpose; that is, basic and needed for day-to-day survival. These are, air, water, food, clothing, shelter, sex, protection from physical danger, task components, activities performed, safe environment of work, and so forth.

These needs are fulfilled by extrinsic factors of work. Pay for instance, because of what Opsahl and Dunnette (1966) termed as its instrumental power to fulfill other desires and its exchange function, is a powerful extrinsic reward and can fulfill a good number of the concrete needs listed above.

Abstract needs are those that bother on the cognitive and the emotional. The needs for friendship, relationship with superior and subordinates, love, self-esteem, responsibility, recognition, growth and autonomy are abstract in nature. The classification of concrete or abstract needs can be made simple if the manager asks whether these needs can be met by extrinsic factors of work or by intrinsic factors. There are three areas of focus in meeting concrete needs (1) Pay, i.e., money is a means of gaining desired outcome. Can offer of money or material provision meet the needs so identified? If so, they are concrete needs. (2) The context of job. This has to do with design of workplace, structure of work and environment of work. These are aspects of work that can be thoughtfully and physically manipulated to meet the need 
for safety, physiological comfort, sound health and so forth. (3) The content of job. With the useful aid of an objective job analysis, the task and human dimensions of work are made easily identifiable in terms of activities to be performed and abilities/experiences that match tasks/activities.

The concept of Job enlargement and enrichment is best understood in the context of appropriate identification and classification of task components not just to distinguish families of job, or different job titles, but to classify tasks together that are relevant in terms of human, physical, mental and emotional attributes required to do them.

In summary concrete needs can be satisfied by the pay procedure, context of work and content of jobs. Abstract needs on the other hand are met essentially by non-material aspect of work such as relationships depicted in styles of leadership, culture and climate of organization.

It may be argued whether while meeting concrete needs, abstract needs are not met at the same time? Where this happens, it is all the better for management. The argument may be extended further by years of concentration (since Herzberg, 1966) on the content of work as an abstract entity. Jobs are described by physical activities engaged in by the incumbent. These activities call on the use of psychomotor, physiological, cognitive and sometimes emotional attributes or skills. The tasks and duties are concrete to the extent that they tap on the use of physical senses of sight, touch, taste, smell and hearing. Performance or otherwise can be physically controlled or reinforced (positively or negatively).

Abstract needs as well as abstract component of work feature prominently in most process theories (Vroom, 1964). One can direct attention on the original motive for working. This motive bothers on the concrete or instrumental use of work to generate other outcomes and the abstract need to work to fulfill other intrinsic needs like enhancement of self-esteem, the need to conform to norm of societal expectation, the need to be responsible, the need to be classified along desired social class, the need to fraternize, etc. Also important is the need to express ones talents, explore abilities, and potentials, grow, and become self-actualized or self-fulfilled. Since concrete and abstract needs can be distinguished, factors leading to their satisfaction also vary. Herzberg has theorized this much in his 2-factor theory of motivation. It could be seen however that concrete and abstract needs are not of the same distinction as hygiene and motivator variables of Herzberg, (1966).

Looking back at figure 2, it is important to note that needs, especially its arousal and intensity, is a function of energy/skill (mental \& physical) and attitude of workers (as individual or acting in conjunction with his formal and informal groups), management as individual or group (formal or informal), owners of business, government, retirees as well as society of operation. The needs of a worker as an individual may not altogether be the same as when he finds him/herself in a group. The needs also in terms of intensity, articulation and presentation vary as member of informal or formal groups.

Managers (middle cadre, senior or directorate) have their different needs as individuals and as groups. A crucial component of modern business is the shareholders and many instances of businesses not directly managed by their owners. These also have their needs as articulated in the philosophies, mission statements, visions and goals of the business. Other vital need components that cannot be ignored are societal, governmental and retirees' needs. Every business is located within the context of a social, political, economic and ecological milieu. This, often viewed as a peripheral component of work, may make its needs felt in a manner that will positively or otherwise affect earlier stated organisational goals in terms of the extent to which they are or can be achieved.

There exist cases of shutdowns, sabotage, etc., of companies and installations in the Niger Delta that derives from none or partial factoring in of the needs of business environment into that of the organization. Government as regulator of the business environment also has legislative power and enforcement agencies to compel fulfillment taxes and rates obligations. Retirees on the other hand have no such and have been treated as an unwanted burden. In reality, all incumbent will end up as retirees. The more it is noted that executives factor their exit into their pay packages and allowances, the more 
current workers will show concern about here and now. It is conceivable that one of the critical considerations, among all work cadres, in corrupt practices is the need to save for the raining days ahead of retirement.

The need-goal hypothesis by clearly demarcating among the constellation of needsk and their categories can assist in helping organisations to identify needs that are germane to operational success, ordering these to match goals of individuals, group (union, management), owners, society, government and organisation's survival needs (productivity, profitability, growth e.t.c.).

\subsection{MOTIVATION: THE NEED FOR A SHIFT OF PARADIGM}

Going by the propositions above, there is a need to do, in full attention, what has been done halfheartedly over the years. The need-goal hypothesis provides a framework for incorporating the needs of all entities that are important to the survival of a business concerns into the goals, activities and actions of the organization.

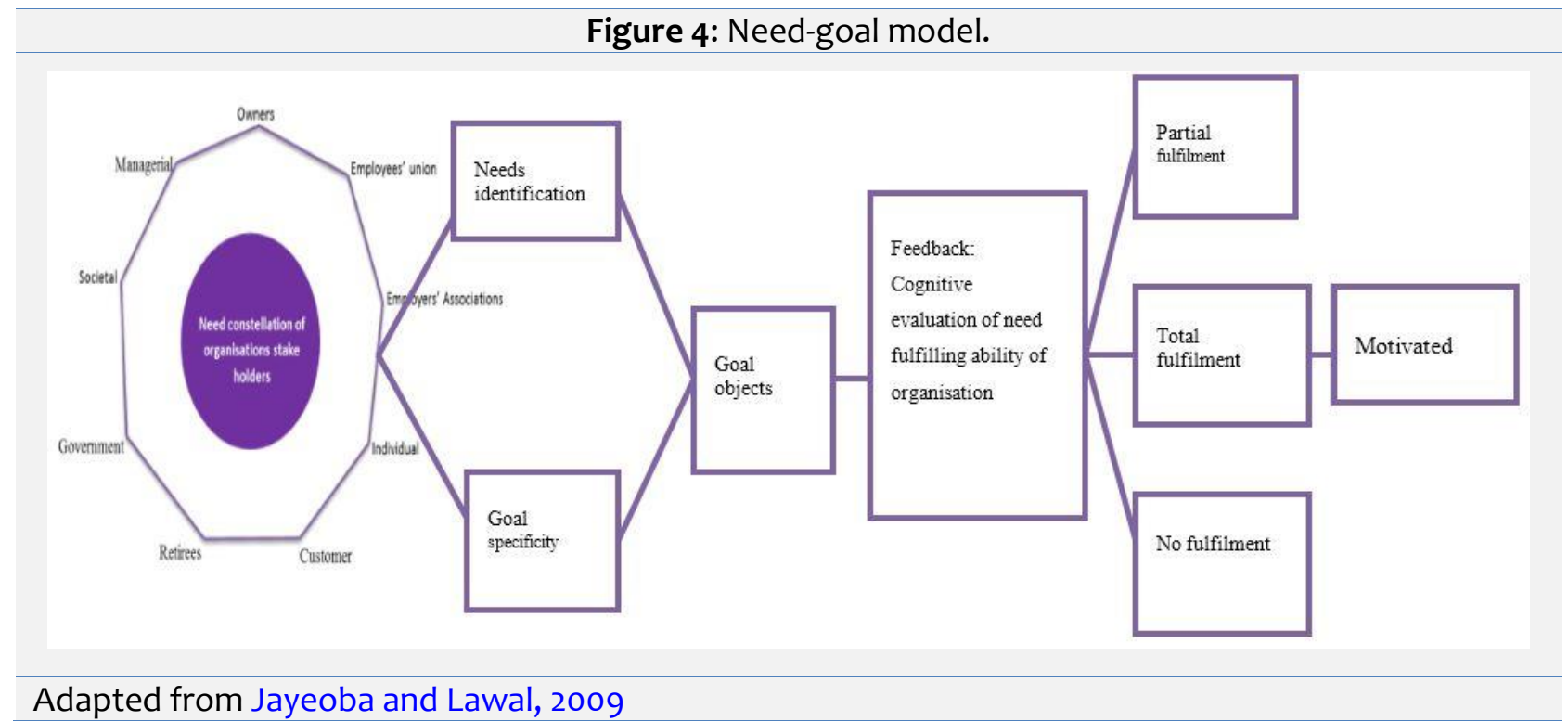

The most important duty of management is to evolve strategy and tool to identify the full extent of needs presenting in the organization. Once needs of specific entities are identified and factored into the operational and reward system in terms of objectives and work roles, valuable goals are set and goal objects identified to meet them in their concrete and abstract content. Goal specificity, matched with identified needs that are fulfilled by goal objects that are derived from work/organization will lead to motivation of workers and all other entities.

The manager that is laden with unfulfilled needs of his team is, as a feedback, demotivated in the sense that a measure of his ability to manage is the level of result obtainable from his team. Once the team fails to meet target, focus is on the manager to adduce reasons for the outcome just as he is commended for meeting performance expectation. Traditionally, members of the team or the team are blamed for shortfall in performance. This approach has led many times to misleading actions like restructuring, reengineering, hiring new hands or firing suspected idlers or even needless expenditure on expensive training and development programmes. The reason for such managerial concern is because motivation and performance are like two edge of the same sword. According to Staw (1986) most prevailing theories of performance are concerned with individual motivation by prescribing various techniques of stimulating, reinforcing or luring people to work harder. It is frequently assumed that if the employee wants to perform better, his or her performance will naturally go up. This view is not altogether true as studies by Dunnette (1976) have shown. 
Mental and physical abilities as well as factors such as personality characteristics, task characteristics, work implement, supply of materials, financial support, energy, social/business infrastructures and pace of work of team members are deemed important in employees and general performance of people. These factors can exist in various degrees in different workplaces leading to variation in motivation and performance of the same employee over different work settings. Also important is individual attitudes and disposition to work. Staw (1986) had shown a pessimistic outlook of employee motivation and performance by indicating that workers attitude and disposition are fairly consistent over time even when people change jobs. Thus performance/motivation to work is a product of disposition and situational sources of job satisfaction. In the light of propositions from the need-goal hypothesis, both attitude and disposition are subsumed in individual's needs and the strategies available (at individual and organisational levels) to implement objectives and goals aimed at meeting salient needs. Job satisfaction and its variants (satisfaction with pay, supervisor, coworkers, and working conditions) as well as life satisfaction can be derived in a work situation that formulate strategies for need identification of constituent members, set jointly defined goals and objectives as well as equitable/realistic yardsticks for assessment of attainment.

The cause(s) of job satisfaction/dissatisfaction can be located by careful analysis of the constellation of needs and the needs that are pre-potent, recognized (or correctly classified and labeled) and satisfied. Where certain aspects of needs are left un-integrated into the need constellation of the organization, a state of imbalance of needs versus goals will be created leading to actions(s) on the part of the segment whose needs are neglected to address felt neglect. Such actions aimed at addressing inequitability of reward, status, participation in decision, perceived skewedness in power locus and distribution of power and so forth are the sources of grievance, industrial actions and needless waste of time at conflict resolution. These results in strikes, loss of productive hours, litigation, etc. which are common phenomena in the Nigerian industrial relations system. Examples range from dysfunctional behavior (absenteeism, lateness, pilfering, moonlighting, turnover intention and turnover) to industrial action by union and community action where the need of the host community is vastly neglected. Such action on the part of the host community may range from poor image of company, poor patronage of products and services, protests and outright sabotage of work processes. Consistent neglect of immediate environmental needs of hosts communities in the Niger Delta by oil companies has led to various acts of agitation; protest, sabotage of installations, hostage taking, violence against personnel and armed struggle and general disruption of economic and social life.

The case of oil companies in the Niger Delta demonstrates the need to embrace the needs that are represented in the enveloping social, geographical and political environment along the needs of organization and factor them into the motivational paradigm to preserve contextual balance within (as well as without) the organization.

Retirees are also waking to the fact that they need to enforce their rights to decent livelihood after work through protests, litigation and other actions meant to either cripple work process or put social/political pressure on their former employers.

\subsection{CONCLUSION}

Motivation is much more than the manager waving carrot or stick to get the subordinates working and going. In several ways, the extent to which organizationally set goals are in consonance with the meeting of the needs of its constituencies is the extent to which motivation can be achieved. Also it is important to note that all the stakeholders to the organisation need to be motivated (identified/acknowledged, appraised in terms of contribution - positive or nuisance value - and rewarded) to ensure continuous playing of roles that will ensure greater productivity and survival into the future.

The motivation to invest is as a result of profitability of initial investment, just like the manager is motivated if his management strategies are working and he/she is meeting needs of investors, customers, workers and self. Ultimately, the level of response and enthusiasm shown towards 
attainment of organisational goals depend equally on the extent to which the employees perceived that the organisation not only recognize his individual and group needs, but is meeting them and is capable of sustaining the trend in the short and long run. Considerations of length of service and turnover are linked to treatment being meted to retiring workers of an organisation. The incumbents are likely to see what becomes of them in the future after retirement in the picture of agonies and privations being experienced by those who had left the organisation before them. This concern had perhaps explained the preference, in spite of lower pay, of the public sector by Nigerian workers. There is perceived job security, retirement benefits (gratuity and pensions). These benefits have however been wiped out by the reviews of the old non-contributory Pension Act in favour of contributory Act which is a sort of pay as you go modality.

\section{REFERENCES}

Adams, J. S. (1965) “Injustice in Social Exchange”, in L. Berkowitz (ed.) Advances in Experinmental social pschology. 267-300.

Alderfer, C. P. (1969) An Empirical Test of a New Theory of Human Needs; Organisational Behaviours and Human Performance. 95-117.

Amaefule, E. (2013) “Move to end multiple taxation”. The Punch. Lagos: Punch Nigeria Limited.

Bandura, A. (1969). Principles of Behaviour Modification. New York: Holt, Rinehart \& winston.

Blum, M. L. \& Naylor, J. C. (2001) Industrial Psychology: Its theoretical and Social Foundations: New Delhi: CBS Publishers and Distributors.

Cameron, K. (1980) "Critical Questions in Assessing organisational Effectiveness". Organisational Dynamics, 66-80.

Cannon, W. B. (1932)Wisdom of the body. New York: Norton.

Chamberlain, N.W.(1951) Collective Bargaining. New York: McGraw-Hill.

Carsrud, A. \& Brannback, M. (2011) "Entrepreneurial Motivations: What do we still need to know?" Journal of Small Business Management, 49 (1). 9-26.

Clegg, H.A.(1960) A New Approach to Industrial Democracy. Blackwell: Basil.

Drucker, P. F. (1954) The Practice of Management. New York: Harper.

Dunnette, M. D. (1976) ‘Aptitudes, Abilities and Skills'.In M. D. Dunnette (Ed.), Handbook oflndustrial and Organisational Psychology. Chicago IL: Rand MCNally.

Dunlop, J.T.(1949) Collctive Bargaining: Principles and Cases. Chicago: Urwin.

Eze, N. (1995). Human Resource Management in Africa: Problems and Solutions. Lagos:Zomex Press.

Fayol, H. (1949). General and Industrial Management. London: Pitman.

Freud, S. (1910) “The Origin and Development of Psychoanalysis”. American Journal of Psychology. 181 218

Georgopolous B. S. Mahoney \& Jones, M. P. R. (1957). "A path-goal theory of productivity". Journal of Applied psychology 41.

Gibson, J. L., Ivancevich, J. M., \& Donnelly, J. H. (1997), Organisations; Behaviour, Strucure, Processes. Botson: Irvin/Mcgraw-Hill.

Herzberg, F. (1966). Work and the Nature of Man. Cleveland; World Publishing Company.

Hofstede, G. (1980), Motivation, Leadership and Organisational Behaviour: Do American Theories Apply A Groad?" Organisational Dynamics. 55-71.

Jacques, E. (1961). Equitable Payment, New York: Wiley.

Jayeoba, F. I. \& Lawal, O. A. (2009) Need-Goal Hypothesis. Management Discoveries,2, 48-65.

Jayeoba, F. I. (2012) ‘Need-goal hypothesis and organisational types; the Industrial relations implications'. European Scientific Journal, 8(19), 229-253.

Jones, M. R. (ed) (1959) Nebraska Symposium on Motivation, Nebraska, V. P. 7.

Kanter, R. (1990) Motivation Theory and Industrial and Organisational Psychology". In M. D. Dunnette and L. M. Hough (Eds) Handbook of Industrial and Organisational Psychology (2ndEd.) 1 Palo Alto, CA: Consulting Psychologists press.

Kosslyn, S. M. \& Rosenberg, R. S. (2001). Psychology; The Brain, the Person, the World. Boston: Allyn and Bacon. 
Kreitner, R \& Kinicki, A. (2001) Organisational Behavior (5th Ed.). Boston: Irwin McGraw-Hill.

Maslow, A. (1943) "A preface to Motivation Theory" Psychosomat, Med. 85 - 92.

Maslow, A. (1954) Motivation and personality. New York: Harper and Row.

Mayo, E. (1933) The human problems of an industrial civilization. New York: Macmillan.

McClelland, D. C. (1961) The Achieving Society. New York. Van Nostrand Reinhold.

Opsahl, R. L. \& Dunnette, M. D. (1966). "The Role of Financial Compensation inIndustrial Motivations". Psychological Bulletin, American psychological Association. 95 - 116.

Passer, M.W. and Smith, R.E.(2001) Psychology: Frontiers and Applications. New York:McGraw-Hill Companies.

Pavlov I. (1928) Lectures on conditioned reflexies Twenty-five years of objective study ofhigher nervous activity (Behaviour) of animals. New York: International Publishers.

Roberts, N. C. \& King, P. J. (1989) “The Stakeholder Audit Goes public”.Organisational Dynamics, 63-79

Robins, S. P. (2001) Oprganisational Behaviour. New Delhi: Prentice - Hall of India Private Limited.

Skinner,B.F. (1938) The Behaviour of Organisation;an experimental analysis. New York: Apleton-Century.

Staw, B. M. (1986) 'Organisational psychology and the pursuit of the happy/productive worker'. California Management Review, 28 (4), 40-53.

Taylor, F. W. (1947). "The Principles of scientific Management”. Scientific Management. 100 - 117.

Vroom, V. H. (1964) Work and Motivation. New York: John Wiley. 